\title{
The anaemia of Plasmodium vivax malaria
}

\author{
Nicholas M Douglas ${ }^{1,2,3^{*}}$, Nicholas M Anstey ${ }^{1,3}$, Pierre A Buffet ${ }^{4,5,6}$, Jeanne R Poespoprodjo ${ }^{1,7,8}$, Tsin W Yeo ${ }^{1,3}$, \\ Nicholas J White ${ }^{2,9}$ and Ric N Price ${ }^{1,2,3}$
}

\begin{abstract}
Plasmodium vivax threatens nearly half the world's population and is a significant impediment to achievement of the millennium development goals. It is an important, but incompletely understood, cause of anaemia. This review synthesizes current evidence on the epidemiology, pathogenesis, treatment and consequences of vivax-associated anaemia. Young children are at high risk of clinically significant and potentially severe vivax-associated anaemia, particularly in countries where transmission is intense and relapses are frequent. Despite reaching lower densities than Plasmodium falciparum, Plasmodium vivax causes similar absolute reduction in red blood cell mass because it results in proportionately greater removal of uninfected red blood cells. Severe vivax anaemia is associated with substantial indirect mortality and morbidity through impaired resilience to co-morbidities, obstetric complications and requirement for blood transfusion. Anaemia can be averted by early and effective anti-malarial treatment.
\end{abstract}

Keywords: Plasmodium vivax, Malaria, Anaemia, Epidemiology, Pathogenesis

\section{Background}

Plasmodium vivax threatens approximately 2.8 billion people globally and, because of its particular biological characteristics, will be more difficult to eradicate than Plasmodium falciparum [1-9]. Over recent years, case series [10-13], surveillance studies [14-17] and reviews [4,18-24] have linked vivax malaria with a number of severe manifestations similar to those found in P. falciparum infection; observations that challenge the notion that vivax malaria is a benign disease. The causative role of $P$. vivax in some of these severe manifestations remains to be proven and many are sufficiently rare that they are unlikely to represent significant public health problems. Anaemia, on the other hand, is a common and frequently severe consequence of vivax infection [14-16,25-27]. This review explores the epidemiology, pathophysiological mechanisms, relationship to transmission dynamics and consequences of anaemia caused by vivax malaria (highlighting similarities and differences as compared with P. falciparum). The impact of anti-malarial treatment on haematological recovery is also described.

\footnotetext{
* Correspondence: nicholas.douglas@gmail.com

'Global Health Division, Menzies School of Health Research PO Box 41096, Casuarina NT 0811 Australia

${ }^{2}$ Centre for Tropical Medicine, Nuffield Department of Clinical Medicine, University of Oxford Oxford UK

Full list of author information is available at the end of the article
}

\section{Epidemiology}

Endemic $P$. vivax is transmitted throughout the tropics in much the same geographical pattern as $P$. falciparum $[1,8]$. The major exception is West Africa where P. vivax is largely absent. This has been attributed to selection over many millennia of individuals lacking the Duffy red blood cell surface antigen - an important mediator of $P$. vivax red cell invasion $[2,28]$. Menard and colleagues' recent discovery of vivax malaria in Duffy negative Malagasy people suggests that $P$. vivax may have escaped its dependence on the Duffy antigen in certain regions [29].

Where P. falciparum and P. vivax co-exist, both the incidence of infection and severity of haematological morbidity attributable to $P$. vivax tends to peak at a younger age than for falciparum malaria and in many regions, before the end of the second year of life [16,27,30-32]. This pattern probably reflects greater parasite exposure through frequent relapse and consequently more rapid acquisition of immunity to vivax malaria. In tropical regions, relapses may occur as often as every three weeks [33,34]. In Papua, Indonesia, an area of comparatively high-level $P$. vivax transmission, approximately a quarter of infants hospitalized with vivax malaria have severe anaemia (haemoglobin less than $5 \mathrm{~g} / \mathrm{dL}$ ), whereas in individuals 45 years or older this proportion decreases to less than 5\% [16]. Infants with vivax malaria in this region have 2.4-fold greater odds of severe anaemia than those with falciparum malaria [27].

\section{Biomed Central}


Females are at greater risk of hospitalization with $P$. vivax malaria than males [16] and in one large analysis were more likely to present with anaemia (unpublished data). Both phenomena may be, at least partially, explained by the fact that post-pubertal women have a lower mean haemoglobin concentration than men and therefore have a greater chance of being tipped over the threshold for anaemia following a haematological insult. Pregnant women with $P$. vivax infection have a $\sim 2$-fold higher risk of moderate anaemia than uninfected pregnant women [35-37]. Whether the haematological impact of vivax malaria in pregnancy is greater than in non-pregnant women of child-bearing age is unknown.

Several red blood cell and haemoglobin variants have been associated with reduced susceptibility to anaemia caused by falciparum malaria, the best known being sickle cell anaemia. Hypothesized mechanisms for this protection include reduced red blood cell invasion, relative inhibition of intracellular parasite replication, more efficient removal of infected red blood cells by the spleen and more efficient presentation of parasite antigens to the immune system [38-40]. The high erythrocyte counts and relative microcytosis seen in conditions such as alpha-thalassaemia result in a lower proportional reduction in haemoglobin with falciparum malaria [41]. Both alpha- and beta-thalassaemia have been associated with an increased risk of $P$. vivax parasitaemia in cross sectional studies but their effect on vivax anaemia is unknown [42-44]. Preliminary work suggests South-East Asian ovalocytosis may protect against $P$. vivax parasitaemia and vivax-associated anaemia [45,46] whereas the effects of Gerbich blood group are unclear [47]. Glucose-6-phosphate dehydrogenase deficiency is associated with protection against clinical disease and reduced parasite density in $P$. vivax infections $[48,49]$. The rarity of such polymorphisms in migrant Highland Papuan populations has been hypothesized to contribute to the higher risk of severe anaemia from $P$. vivax in Southern Papua compared with elsewhere in New Guinea [22].

Gastrointestinal helminth infections may cause anaemia through chronic blood loss, but the interaction with malarial anaemia is complex. In Africa, hookworm and P. falciparum malaria coinfection has been shown to cause an additive reduction in haemoglobin in children and pregnant mothers when compared with monoinfection with either parasite alone [50]. Helminthiasis may also be a risk factor for $P$. falciparum parasitaemia but evidence is conflicting [51,52]. Few studies have addressed the effect of intestinal helminthiasis on the risk of $P$. vivax infection and vivax-associated anaemia. Boel and colleagues showed a positive association between Ascaris lumbricoides infection during pregnancy and risk of vivax malaria [53]. Another small study found that the reduction in haemoglobin associated with
P. vivax infection in children between five and 14 years of age was attenuated by coinfection with hookworm, A. lumbricoides and Trichuris trichuria [54].

The haematological effects of chronic blood loss caused by intestinal helminthiasis are exacerbated by nutritional iron deficiency which in turn may interact with the haematological effects of $P$. vivax malaria. Iron deficiency is protective against $P$. falciparum infection whereas iron supplementation increases the risk of falciparum malaria and high parasitaemia infections $[55,56]$. The evidence for a link between iron supplementation and morbidity associated with vivax malaria is conflicting. One large prospective study from Thailand showed that pregnant women given supplemental iron and folate were at increased risk of $P$. vivax infection compared to those who did not receive supplementation [57]. A randomized controlled trial from Peru showed that iron plus zinc reduced vivax-associated morbidity in children under five years of age, but iron supplementation increased morbidity in those over five years [58]. In Papua New Guinea, 16 weeks of supplemental iron in prepubescent school children provided an overall haematological benefit compared with placebo and had no effect on the risk of morbidity associated with vivax malaria [59]. Large, multi-centre trials including both pre- and post-pubescent participants are required to firmly establish whether an association between iron status and vivax anaemia exists.

\section{Pathophysiology and mechanisms}

The primary target of human Plasmodium species is the red blood cell. Plasmodium vivax has a very strong predilection for red blood cells that have emerged from the bone marrow within the last 14 days, in particular reticulocytes, whereas $P$. falciparum has only a moderate predilection for young red blood cells and significant ability to infect older cells [60-62]. The natural history of erythrocytes infected by either species is to host the replicating parasite for approximately 48 hours before bursting and releasing daughter merozoites. The range of peripheral parasitaemia in $P$. vivax infections is lower than in symptomatic $P$. falciparum malaria and parasitaemia $>2 \%$ is rare [9]. Despite this, mathematical models suggest that premature death of infected reticulocytes due to $P$. vivax infection should be sufficient to lead to extreme anaemia over a period of several months by choking the supply of mature red blood cells [63-65]. Direct evidence from two malariatherapy patients studied in detail shows that severe anaemia may develop much more rapidly than this and that the proportion of infected reticulocytes after two to three weeks of vivax malaria can be less than $10 \%$ [60]. These observations suggest that other mechanisms of anaemia are likely to be important. In $P$. falciparum malaria, these include increased removal of infected, and 
to a greater extent, uninfected red blood cells from circulation, compounded, in subacute and chronic forms, by impaired erythropoiesis [66-70]. The same general processes appear to be important in vivax malaria but many of the cellular mechanisms differ (see Figure 1 $[9,27,60,61,63,64,66-104])$.

\section{Removal of red blood cells from circulation}

Although parasitaemia is typically lower in vivax compared with falciparum infections, the absolute number of red blood cells removed from circulation, and hence the degree of anaemia resulting from infection by the two species, is often similar $[16,26,105]$. This is because in $P$. vivax malaria, approximately 34 non-infected cells are cleared for every one infected cell [73] whereas in P. falciparum malaria, this ratio is closer to 8 to $1[67,70]$. These figures are derived from observations in non-immune adults treated for neurosyphilis $[67,73]$ and Thai patients over $5 \mathrm{~kg}$ in weight [70]. There are no data on the proportional removal of uninfected red blood cells in infants, the age group bearing the greatest burden of anaemia due to vivax malaria. Although removal of uninfected red blood cells is an important component of vivax-associated anaemia, the mechanisms of removal are not fully understood.

As in falciparum malaria, vivax-infected erythrocytes adhere to uninfected red blood cells (rosetting) [106,107] but unlike falciparum-infected cells, they have limited propensity to adhere to endothelial cells and, therefore, sequestration in the deep microvasculature is not a major factor in the pathogenesis of vivax malaria $[108,109]$. Erythrocytes parasitized by P. falciparum become less deformable than uninfected red cells and have reduced capacity to pass through narrow interendothelial slits in the wall of splenic sinuses (mean dimensions $1.89 \times 0.65 \mu \mathrm{m})[85-87,110]$. Vivax-infected cells become more deformable as the parasite matures and are thought to retain the ability to squeeze through splenic slits $[81,110,111]$. In falciparum malaria, red blood cell sequestration reduces the proportion of parasitized red blood cells that traverse the spleen. Increased deformability of infected red blood cells in vivax malaria may limit the proportion of red cells that are removed during passage through the splenic microcirculation. Thus, it appears that $P$. falciparum and $P$. vivax have evolved two different means of escaping splenic filtration. In both vivax and falciparum malaria, parasitized, and possibly non-parasitized, red cells are hypothesized to be more fragile than red cells in non-infected individuals and more prone to damage from shear stresses $[72,81,110,112]$. This process is potentially a more important cause of red cell loss in falciparum malaria since in this disease, major sequestration in the microvasculature impedes the passage of circulating erythrocytes and erythrocyte rosettes [82].
In addition to these mechanical processes, activation of the innate, cell-mediated and humoral immune systems in response to the presence of $P$. vivax antigens enhances the detection and removal of infected and abnormal uninfected red blood cells $[69,75,113]$. The non-specific immune response for a given parasitaemia is greater for $P$. vivax than $P$. falciparum and may partially explain the greater proportional removal of non-parasitized cells and lower fever threshold in vivax malaria [114-116]. This is a relatively weak speculation however since in severe falciparum malarial anaemia, cytokine levels are generally lower than in cerebral or uncomplicated attacks $[96,97]$ and cytokine concentrations have not been found to correlate with the degree of anaemia in $P$. vivax infections [105]. Macrophage hyperplasia and increased phagocytic activity in both falciparum and vivax malaria results in a highly oxidative environment and may contribute to the shortened lifespan of non-infected erythrocytes [75,117-121]. To compound the problem, reduced glutathione, which is necessary for protecting red cells against damaging oxygen species, is reported to be depleted in vivax malaria $[93,122]$. Infection with P. falciparum causes altered expression of complement components and deposition of parasite proteins on infected and uninfected red blood cells $[88,92]$ (the latter sometimes associated with presence of specific immunoglobulins); facilitating opsonization and complementmediated phagocytosis $[89,91,123]$. It is unknown whether these processes also occur in vivax anaemia.

Whatever the mechanisms leading to red blood cell alteration, the spleen is the most important site for the filtration, retention and phagocytosis of non-sequestered erythrocytes parasitised or altered by $P$. falciparum [87,124-127]. Splenic activity limits parasite density thereby reducing the risk of severe malaria. However, the more stringent the splenic clearance, the greater the likelihood of severe anaemia $[124,125,128]$. This may explain why concomitant severe malarial anaemia with spleen enlargement and cerebral malaria is relatively unusual with cerebral manifestations being more common in acute, fulminant infections and anaemia being more likely in chronic infections $[27,76,128,129]$. The role of the spleen in vivax malaria is poorly understood though splenic enlargement in this infection appears to be similar to falciparum malaria $[130,131]$. Indeed vivax malaria carries a very low but well-known risk of splenic rupture; considered greater than for falciparum malaria $[132,133]$. In 1974, Littman described a single patient with hereditary spherocytosis who developed severe anaemia secondary to vivax malaria. A relapse five months later after a splenectomy did not cause anaemia suggesting that the spleen was the primary site of red blood cell removal (though the effect of strain specific immunity could not be excluded) [134]. A study from Papua showed that plasma haemoglobin 


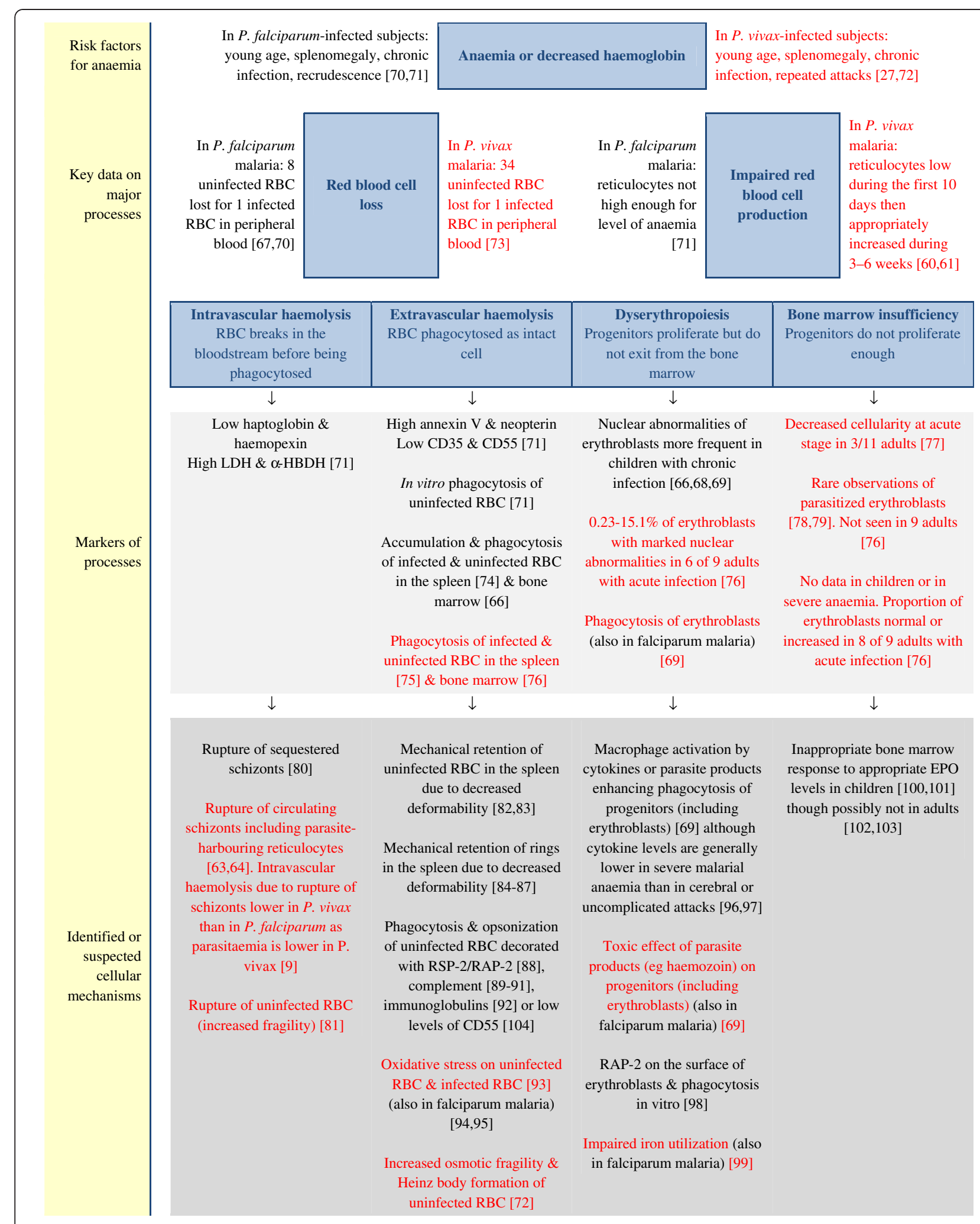

Figure 1 Comparative pathogenic mechanisms of anaemia associated with $P$. vivax and $P$. falciparum malaria (mechanisms in red font relate to vivax malaria and mechanisms in black relate to falciparum malaria). Abbreviations: RBC; red blood cell, CD35; complement receptor 1, CD55; decay accelerating factor, $\mathrm{LDH}$; lactate dehydrogenase, $\mathrm{a}-\mathrm{HBDH}$; alpha-hydroxybutyrate dehydrogenase, RSP-2; ring surface protein 2, RAP-2; rhoptry-associated protein-2, EPO; erythropoietin. 
concentrations in adults with uncomplicated vivax malaria were not increased compared to controls and were significantly lower than in falciparum malaria (unpublished data). This suggests that in adults with vivax malaria, the degree of intravascular haemolysis may be less than in falciparum malaria and that a greater proportion of uninfected red blood cells undergo extravascular removal.

Increased removal and destruction of both infected and uninfected red cells in vivax malaria is most prominent during the early stages of infection however enhanced removal of uninfected cells persists for five weeks or more after effective treatment of blood-stage infection $[135,136]$. In chronic, asymptomatic vivax parasitaemia, common in vivax-endemic areas, removal of both infected and uninfected red cells is likely to persist for the duration of infection.

\section{Impaired production of red blood cells}

Patients with vivax or falciparum malaria have bone marrow abnormalities reflecting impaired erythropoiesis. In the earliest stages of both infections, the typical marrow finding is of decreased cellularity [69,77]. In those with more chronic infections, marrow cellularity tends to be normal or increased but there is ineffective erythropoiesis [66,68,76], as indicated by impaired iron utilization $[69,99]$, presence of morphologically abnormal erythroblasts as a result of cellular injury [76], and phagocytosis of erythroblasts by marrow macrophages $[69,76]$.

The exact mechanisms and functional importance of impaired erythropoiesis in vivax malaria are unclear. Using electron microscopy, $\mathrm{Ru}$ and colleagues have shown parasitization and subsequent degradation of erythroblasts in two patients with uncomplicated vivax malaria [78]. Yoeli demonstrated morphologically normal, but non-pigmented, intracellular $P$. vivax parasites in a sternal tap specimen but not in peripheral blood smears in a single patient with vivax malaria [79]. Wickramasinghe did not find any $P$. vivax parasites in the marrows of nine Thai adults with uncomplicated $P$. vivax infections [76]. Because of the absence of any bone marrow data in children, or at any age with severe vivax-associated anaemia, the importance of $P$. vivax parasitization of erythroblasts in severe vivax anaemia is not known. Hypoxia of the bone marrow resulting from obstruction of marrow sinusoids by parasitized red blood cells and inadequate erythropoietin production or response have been hypothesized to contribute to impaired erythropoiesis in $P$. falciparum infections [76,102,103,137-139]. In vivax malaria, hypoxia of the bone marrow is unlikely to be significant as there is minimal schizont sequestration. Erythropoietin metabolism is yet to be studied in this disease.

Wickramasinghe and colleagues proposed that P. vivax has a directly toxic effect on erythroblasts or their precursors [76]. Alternatively $P$. vivax may exert its effect on bone marrow macrophages leading to increased phagocytic activity and/or release of locally cytotoxic molecules damaging surrounding haematopoietic cells [76]. Whatever the cause, some degree of impaired erythropoiesis has been shown to persist for at least two weeks after treatment of vivax malaria and therefore the effects of these putative factors must be long-lasting [76].

\section{Effects of transmission intensity, relapse patterns, and strain diversity}

Since a significant proportion of the anaemia of vivax malaria, at least in the acute phase, can be explained by removal of uninfected red cells in response to immune system activation, the magnitude of the immune response (of which intensity of symptoms can be taken as a proxy) is likely to be an important determinant of haematological impairment. Untreated primary sporozoite-induced infection in non-immune adult patients with neurosyphilis typically results in paroxysmal fever lasting 3-8 weeks followed by an extended period of increasing clinical 'tolerance' to persistent parasitaemia [140]. Anti-parasite immunity that suppresses parasitaemia to subpatent levels takes significantly longer to develop, in many cases more than 200 days [141]. Collins and colleagues have reviewed the natural history of haemoglobin changes associated with untreated Plasmodium vivax infection in adult neurosyphilis patients [73]. There was an exponential decay in mean haemoglobin concentrations during the first 4-5 weeks followed by a gradual climb in concentrations coinciding with development of parasite tolerance (see Figure 2). With persistent infection, mean haemoglobin levels had still not returned to normal by week 11 though the trajectory of the changes suggests that they might eventually have done so [73].

Repeat infection with the homologous $P$. vivax strain, whether due to reinfection, recrudescence or relapse, during the period of parasite tolerance may result in a transient rise in parasitaemia but rarely recurrent or exacerbated symptoms [142-144]. Homologous re-exposure after an extended period of parasite exposure (approximately 6 months for the St Elizabeth strain [141]) from untreated or inadequately treated primary infection, relapse or reinfection results in neither patent parasitaemia nor clinical symptoms [142,143,145-148]. Since homologous re-exposure in tolerant or immune individuals causes little non-specific immune system activation, the haematological effects of this are likely to be minimal.

Heterologous immunity however, is weak and exposure to a new strain following primary infection will usually result in clinical malaria with non-specific immune system activation, recurrent symptoms and presumably a repeat haematological insult $[144,149]$. If this occurs before an individual's haemoglobin concentration has returned to normal following primary infection, the haematological effects are likely to be additive though direct evidence supporting this postulate is limited $[33,72,150]$. The likelihood 


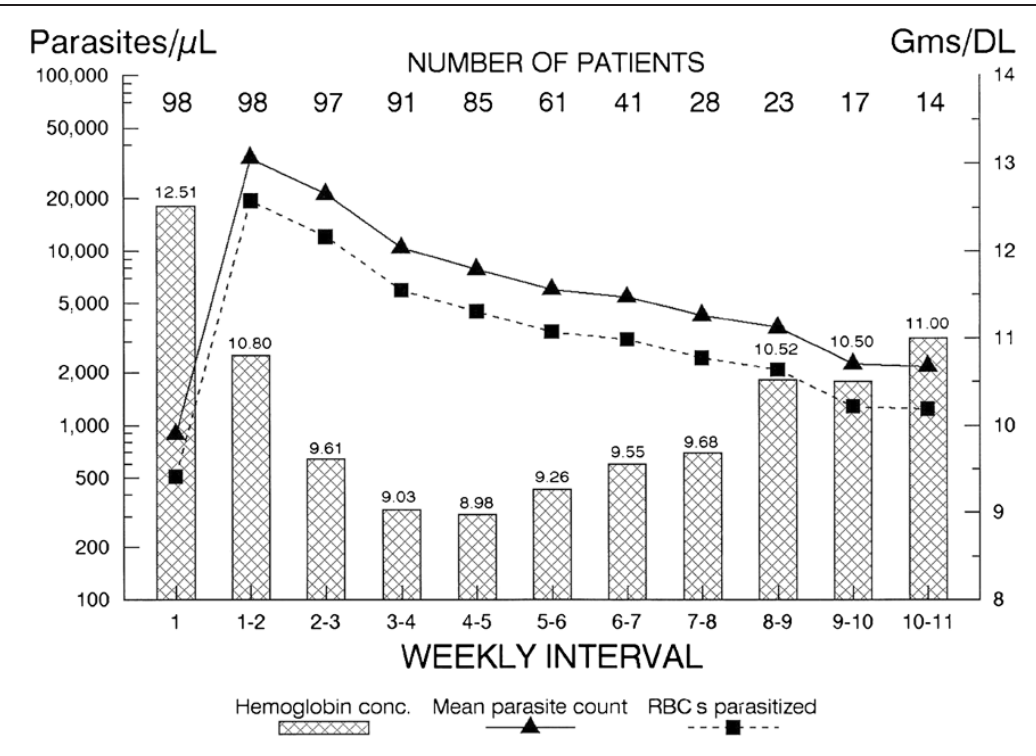

Figure 2 Mean haemoglobin concentration in relation to parasitaemia in patients with syphilis treated with induced $P$. vivax infections (98 with the St Elizabeth strain, 11 with the Chesson strain and 2 with the Korean strain). Reproduced with permission from Collins WE, et al. [73].

of repeat heterologous infection, and the probability that it occurs before complete haematological recovery, is a function of, among other things, the relapse pattern of local $P$. vivax strains and the entomological inoculation rate, both of which are also likely to affect the rate of genetic recombination and hence parasite population diversity [151].

In endemic regions, a high proportion of $P$. vivax relapses are known to be caused by heterologous strains (with regard to the previous vivax infection) [152,153]. This is likely to be particularly common in areas with relatively intense $P$. vivax transmission and/or extensive parasite strain diversity. In such regions, there will also be a greater chance of simultaneous inoculation of two different strains of $P$. vivax which has been shown to cause deficient homologous immunity and therefore presumably greater susceptibility to the haematological effects of future homologous infection [154].

Different $P$. vivax strains have markedly different relapse patterns and in some instances may not even cause a primary infection $[34,141,155]$. In tropical regions, relapses tend to occur regularly every three to four weeks and rarely persist for more than four years from the time of initial inoculation [33]. In temperate climes, the period between relapses may be significantly longer and more variable with some strains showing a bimodal frequency pattern [33]. Tropical strains with short relapse intervals will be more likely to cause repeat blood stage infection before complete haematological recovery has occurred and may therefore be expected to have the greatest haematological impact.
The virulence of an individual parasite strain may also modulate its haematological effects. There is some evidence that the Chesson strain causes fever at lower parasitaemia than other strains and therefore that it may be more immunogenic [156]. In 1947, Whorton and colleagues described the anaemia associated with this strain as "striking" stating that "after the second week of malaria [in malariatherapy patients], it was difficult to maintain patients' erythrocyte count above 2 million per $\mathrm{cmm}$ [corresponding to a haemoglobin concentration of approximately $6 \mathrm{~g} / \mathrm{dL}$ ] in spite of frequent erythrocyte transfusions" [156].

Given the aforementioned evidence, one might predict that the severest haematological impact of vivax malaria would be seen in tropical regions with high entomological inoculation rates and virulent circulating strains. These features are perhaps best exemplified by $P$. vivax on the island of New Guinea where the frequently relapsing Chesson strain is endemic and local populations experience particularly severe haematological impairment from vivax malaria [14-16,27]. In these regions, broad anti-disease immunity to all circulating parasite strains is also likely to develop more rapidly and therefore the haematological burden of vivax malaria will be most heavily skewed to very young children [30].

Most populations at risk of $P$. vivax infection are also exposed to $P$. falciparum and co-infection (not necessarily patent) with these two species is common [150,157-159]. In Thailand, mixed infection with $P$. falciparum and $P$. vivax has been shown to attenuate the risk of severe anaemia 
associated with falciparum malaria - possibly due to some degree of cross-species immunity [70,160-162]. Recent work has shown that in Papua New Guinea and Papua, Indonesia, mixed infection causes more severe haematological impairment than infection with either species alone $[14,16,27]$. The explanation for these opposing findings probably lies in the different transmission dynamics in these regions. In Thailand, severe falciparum malaria is usually the result of a single, fulminant infection in a non-immune individual and therefore earlier induction of suppressive non-specific immunity provided by coincident $P$. vivax infection, however minor, is likely to have a protective effect. In New Guinea, where transmission is more intense, severe anaemia in those older than one year is more likely to be the result of repeated or continuous infections due to either species. In this situation, the haematological effects of infection with both species are more likely to be additive and any immunomodulatory effects relatively minor.

\section{Effects of anti-malarial treatment}

Early treatment of malaria can truncate the impending reduction in haemoglobin and accelerate haematological recovery $[70,163,164]$. Despite the overall benefits of treatment, haemoglobin typically falls slightly following initiation of an anti-malarial drug reaching a nadir between days three to 7 following treatment [70,165]. Data are sparse but there is some evidence that this initial fall may be less pronounced following treatment of vivax malaria with chloroquine (which gives faster clinical and parasitological responses against sensitive strains) compared with either sulfadoxine + pyrimethamine or chlorproguanil+dapsone [165]. The artemisinin derivatives cause an extremely rapid reduction in $P$. vivax parasite biomass. They also temporarily reduce red blood cell production [166-168]. In falciparum malaria, evidence suggests that the haematological benefit of the greater efficacy of the artemisinin drugs negates or outweighs the detrimental effects of this bone marrow suppression $[169,170]$. The only published comparative assessment of the acute haematological effects of treatment with an artemisinin derivative in patients with vivax malaria showed that artesunate + pyronaridine was associated with a greater mean reduction in haemoglobin at days 3 and 7 when compared with chloroquine alone, although no tests of statistical significance were given [167].

Complete removal of blood stage parasites following blood schizontocidal treatment allows faster haematological recovery (pre-infection haemoglobin concentrations are generally achieved in approximately 4-5 weeks following effective treatment [70,163,171,172]) but reduces total parasite exposure and hence limits the development of homologous immunity [146]. Treated individuals are therefore more likely to develop clinical malaria with significant haematological impairment following repeat homologous infection [146,148,173]. Highly efficacious blood schizontocidal regimens containing slowly eliminated drugs (such as chloroquine, piperaquine or mefloquine) minimize the risk of recrudescence and also provide extended post-treatment prophylaxis against recurrent infection, allowing more time for full haematological recovery $[5,150,163,174,175]$. The haematological benefit of the long elimination halflife is likely to be greatest in equatorial regions where $P$. vivax strains relapse as often as every three weeks.

Plasmodium vivax has developed high-grade resistance to chloroquine in parts of Oceania, Asia, Africa and Latin America $[4,5]$ and sulfadoxine + pyrimethamine in parts of South-East Asia [176]. Clinically, drug resistance is manifest by delayed parasite clearance times, an increased likelihood of incomplete parasite clearance and subsequent recrudescence as well as a shorter period of post-treatment prophylaxis against early recurrence [5]. These factors are likely to result in a greater haematological insult associated with the initial infection (as demonstrated in P. falciparum malaria $[70,164,177])$ but may facilitate earlier development of anti-disease immunity.

Primaquine is a hypnozoitocidal drug that, if administered correctly, can prevent $P$. vivax relapses and thus reduce the total haematological impact of a given infection. Unfortunately this medication has the potential to cause lysis of old red blood cells in all patients, but particularly those with glucose-6-phosphate dehydrogenase deficiency [178,179]. G6PD deficiency is the most common heritable enzymopathy in the world, with a prevalence ranging from $7.5 \%$ in Africa as a whole to $2.9 \%$ in the Pacific [180]. Although G6PD deficiency increases the susceptibility of erythrocytes to oxidative damage this alone is not sufficient to account for primaquine-induced haemolysis [181,182]. Generally, the more severe the enzyme deficiency, the greater the severity of haemolysis $[178,179]$. Individuals who have less than $10 \%$ of normal enzyme activity are at risk of lifethreatening haemolysis after as little as one dose of primaquine [183] whereas those with milder variants may have negligible effects [178]. Weekly, as opposed to daily, dosing schedules mitigate primaquine-induced haemolysis [184] whilst retaining efficacy [185] though adherence to such regimens is likely to be poor unless therapy is supervised. In mildly deficient individuals, continuous daily primaquine dosing causes acute but self-limited haemolysis for approximately 10 days followed by reactive reticulocytosis and haematological recovery as the population of old, susceptible, red blood cells is replaced by young erythrocytes [184]. Since this is not an immunological phenomenon, repeat challenge with primaquine after a period of time in such patients causes equally severe haemolysis [179]. In severely deficient patients, haemolysis is progressive and can have a fatal outcome unless primaquine therapy is stopped and blood transfusion given [186,187]. 


\section{Consequences of vivax anaemia}

The impact of Plasmodium vivax infection on haemoglobin concentration varies from negligible to dramatic [10,14$16,188,189]$. The clinical consequences of the reduction in haemoglobin depend on the haemoglobin concentration prior to infection. For example, an absolute reduction of $2 \mathrm{~g} / \mathrm{dL}$ would be more likely to have dramatic consequences if the initial haemoglobin was $6 \mathrm{~g} / \mathrm{dL}$ than if it was $12 \mathrm{~g} / \mathrm{dL}$.

In Papua New Guinea, 1.6\% of children under 5 years of age presenting to rural health clinics for treatment of vivax malaria were severely anaemic (haemoglobin $<5 \mathrm{~g} / \mathrm{dL}$ ) [14]. Across the border in Indonesian Papua, 22\% of patients of all ages who were admitted to hospital with vivax malaria fulfilled criteria for severe anaemia [16]. In the D'Entrecasteaux Islands off Papua New Guinea, a cross-sectional survey of children between 0 and 6 years of age showed that the mean haemoglobin in those with $P$. vivax parasitaemia was $8.7 \mathrm{~g} / \mathrm{dL}, 0.3 \mathrm{~g} / \mathrm{dL}$ lower than the equivalent value for those infected with P. falciparum [190]. In contrast, on the Thai-Myanmar border, less than $0.2 \%$ of patients presenting for treatment of vivax malaria were severely anaemic [189].

Although the spectrum of anaemia seen with vivax infection is reasonably well documented, the clinical, developmental, and socioeconomic consequences are largely unknown. Severe anaemia in isolation is associated with a 2-fold increased risk of death in African children with falciparum malaria and has an even higher mortality when combined with other manifestations of severe disease such as cerebral malaria or respiratory distress [129]. Severe anaemia of any cause in hospitalized children under five years has been associated with a case fatality of between $2 \%$ and $29.3 \%$ and moderate or severe anaemia has been associated with a maternal case fatality of between $<1 \%$ and $>50 \%$ in hospital-based studies [191,192].

Population-based estimates of mortality in severely anaemic individuals with vivax malaria have not been established but recent studies from Latin America, New Guinea and the Indian subcontinent have identified deaths in patients with severe vivax anaemia [10,15-17]. The authors did not establish the extent to which anaemia contributed to those deaths.

Anaemia caused by vivax malaria is associated with requirement for blood transfusion [188,189]. Screening of blood products for pathogens is well known to be incomplete in many low and middle income countries and therefore has a significant attendant risk of pathogen transmission [193]. For example, in Sub-Saharan Africa, estimates for the risk of transfusion-associated infection with HIV, hepatitis B and hepatitis C are 1, 4.3 and 2.5 infections per 1,000 units of blood respectively [194].

Pregnant women with haemoglobin concentrations under $8 \mathrm{~g} / \mathrm{dL}$ in Papua New Guinea were at 2.4-fold higher risk of delivering a low birth weight baby than non-anaemic mothers [195]. In this study, primigravidae with anaemia and parasitaemia at the time of delivery had the greatest risk of low birth weight [195]. Although vivax malaria is endemic in Papua New Guinea, attribution of these effects specifically to this species is not possible [195]. In Papua, Indonesia, $P$. vivax parasitaemia at delivery is associated independently with an increased risk of moderate anaemia and a mean reduction in birth weight of $108 \mathrm{~g}$ [35].

Although evidence is lacking it seems plausible that severe vivax anaemia may reduce resilience to other infectious and non-infectious diseases and therefore may be associated with indirect mortality. In 1938, Swellengrebel and de Buck reported that 62 (7.7\%) of a series of 807 patients with syphilis who were treated with induced $P$. vivax infections subsequently died; those with other comorbidities were at particularly great risk [196].

Chronic or repeated episodes of malarial anaemia due to any Plasmodium species have been associated with adverse effects on physical and cognitive development as well as school attendance; all of which may be exacerbated by concomitant malnutrition [197-202]. Again, whether these outcomes are generalizable to vivax malaria, and more specifically the haematological effects of this species, is unknown.

\section{Conclusions}

Haematological morbidity associated with $P$. vivax infection is greatest in young children, especially in tropical countries such as Papua New Guinea and Eastern Indonesia where transmission is intense and local parasite strains relapse very frequently. In these regions, vivax malaria is commonly associated with severe anaemia both in the health care and community setting. The haematological effects of vivax malaria are likely to have complex interactions with gastrointestinal helminth infection, haemoglobin and red blood cell abnormalities and malnutrition.

Removal of uninfected red blood cells is a particularly important mechanism of anaemia in acute vivax malaria. Plasmodium vivax-infected red blood cells are minimally adherent and are more deformable than P. falciparuminfected erythrocytes resulting in relatively little red blood cell sequestration in the microvasculature and marrow sinuses and passage of a greater proportion of red cells through the spleen and other reticuloendothelial organs. The role of the spleen in the pathogenesis of vivax anaemia, particularly the removal of uninfected red blood cells, is an important area for future research (Figure 3).

As the global control and elimination of malaria progresses, $P$. vivax is set to become the dominant Plasmodium species $[4,203]$, yet the health, developmental and socioeconomic consequences of vivax malaria and vivax-associated anaemia have received very little attention. Severe vivax anaemia may cause significant morbidity and indirect 
mortality via association with impaired resilience to infectious and non-infectious comorbidities, obstetric complications and requirement for blood transfusion (with attendant risk of blood-borne pathogen transmission). Early treatment with an efficacious blood schizontocide can reduce the initial fall in haemoglobin associated with vivax infection and thus help to prevent adverse outcomes associated with severe anaemia. Reliable prevention of recurrent haematological insults caused by relapses will require hypnozoitocidal therapy. Primaquine is the only licensed hypnozoitocidal agent available and can exacerbate haemolysis in individuals with G6PD deficiency. Policymakers need to weigh the potential benefits of this drug against the risks based on the local prevalence of this enzymopathy as well as the availability of G6PD testing. Vivax-associated anaemia is an important public health concern that underscores the importance of reducing global transmission of P. vivax.

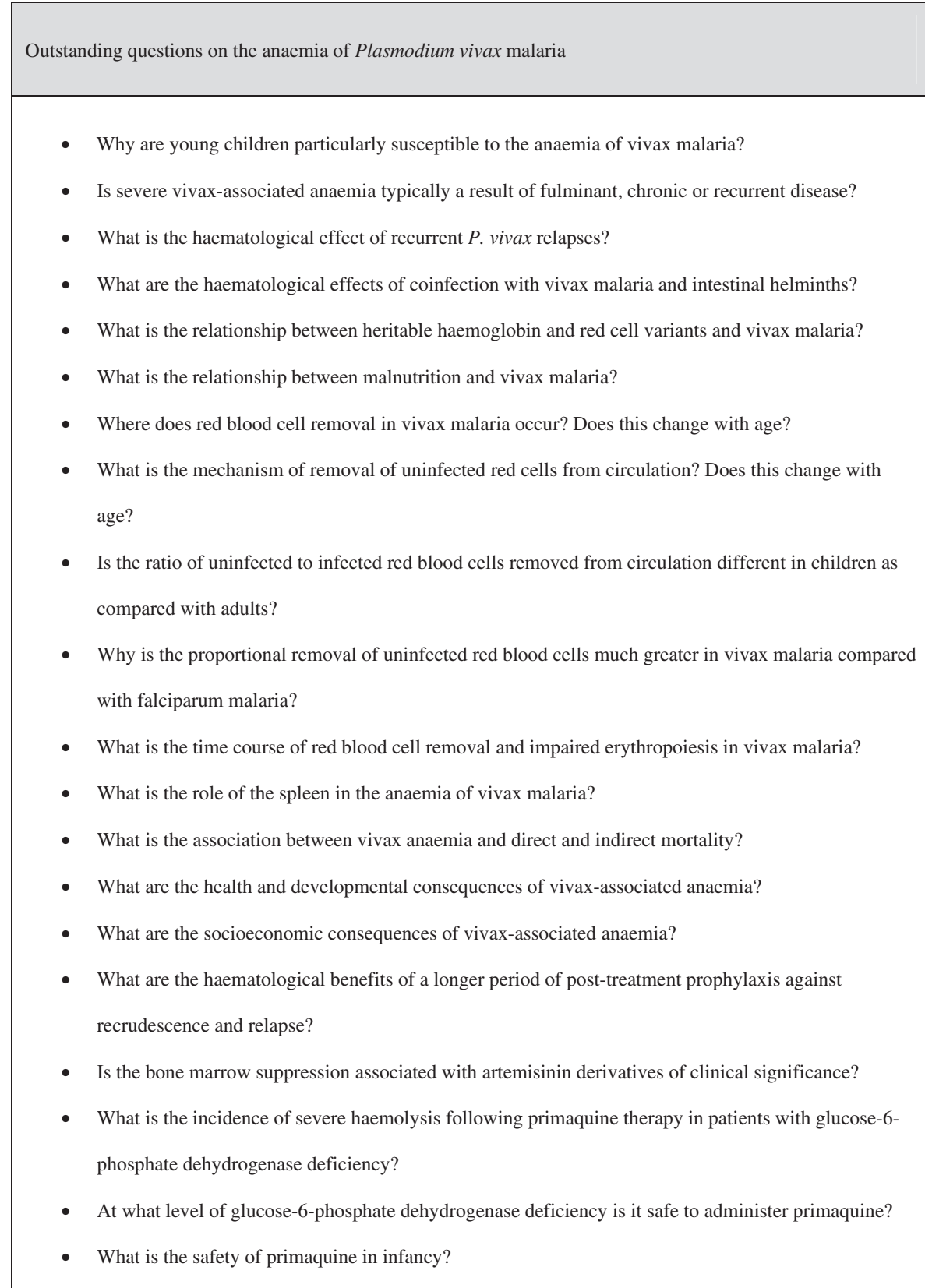

Figure 3 Outstanding questions on the anaemia of Plasmodium vivax malaria. 


\section{Competing interests}

All authors declare they have no competing interests.

\section{Acknowledgements}

NMD received funding from the Rhodes Trust. NMA and TWY are supported by National Health and Medical Research Council Practitioner Fellowships. NJW is a Wellcome Trust Principal Research Fellow and RNP is a Wellcome Trust Senior Research Fellow in Clinical Science.

\section{Author details}

'Global Health Division, Menzies School of Health Research PO Box 41096, Casuarina NT 0811, Australia. ${ }^{2}$ Centre for Tropical Medicine, Nuffield Department of Clinical Medicine, University of Oxford, Oxford, UK. ${ }^{3}$ Division of Medicine, Royal Darwin Hospital, Darwin, NT, Australia. ${ }^{4}$ INSERM - UPMC, (Paris 6 University) UMRs945, F-75013 Paris, France. ${ }^{5}$ Department of Parasitology, Pitié-Salpétrière Hospital, Assistance Publique - Hôpitaux de Paris, F-75013 Paris, France. ${ }^{6}$ Institut Pasteur, Unité d'Immunologie Moléculaire des Parasites, Département de Parasitologie Mycologie F-75015, Paris, France. ${ }^{7}$ Mimika District Health Authority Timika, Papua Indonesia. ${ }^{8}$ Papuan Health and Community Development Foundation, Timika, Papua Indonesia. ${ }^{9}$ Faculty of Tropical Medicine, Mahidol University, Bangkok, Thailand.

\section{Authors' contributions}

$N M D, P A B, N M A$ and RNP searched the relevant literature. NMD wrote the first draft of the manuscript. All authors appraised and revised the manuscript. All authors gave final approval for submission of the manuscript.

Received: 19 February 2012 Accepted: 17 April 2012

Published: 27 April 2012

\section{References}

1. Guerra CA, Howes RE, Patil AP, Gething PW, Van Boeckel TP, Temperley WH, Kabaria CW, Tatem AJ, Manh BH, Elyazar IRF, Baird JK, Snow RW, Hay SI: The international limits and population at risk of Plasmodium vivax transmission in 2009. PLoS Negl Trop Dis 2010, 4:e774.

2. Carter R, Mendis KN: Evolutionary and historical aspects of the burden of malaria. Clin Microbiol Rev 2002, 15:564-594.

3. Galinski MR, Barnwell JW: Plasmodium vivax: who cares? Malar J 2008, 7 (Suppl 1):S9.

4. Price RN, Tjitra E, Guerra CA, Yeung S, White NJ, Anstey NM: Vivax malaria: neglected and not benign. Am J Trop Med Hyg 2007, 77:79-87.

5. Douglas NM, Anstey NM, Angus BJ, Nosten F, Price RN: Artemisinin combination therapy for vivax malaria. Lancet Infect Dis 2010, 10:405-416.

6. Rosenberg R: Plasmodium vivax in Africa: hidden in plain sight? [erratum appears in Trends Parasitol 2007; 23:304]. Trends Parasitol 2007, 23:193-196.

7. Mendis K, Sina BJ, Marchesini P, Carter R: The neglected burden of Plasmodium vivax malaria. Am J Trop Med Hyg 2001, 64:97-106.

8. Guerra CA, Snow RW, Hay SI: Mapping the global extent of malaria in 2005. Trends Parasitol 2006, 22:353-358.

9. McKenzie FE, Jeffery GM, Collins WE: Plasmodium vivax blood-stage dynamics. J Parasitol 2002, 88:521-535.

10. Kochar DK, Das A, Kochar SK, Saxena V, Sirohi P, Garg S, Kochar A, Khatri MP, Gupta V: Severe Plasmodium vivax malaria: a report on serial cases from Bikaner in Northwestern India. Am J Trop Med Hyg 2009, 80:194-198.

11. Beg MA, Sani N, Mehraj V, Jafri W, Khan MA, Malik A, Menezes E, Hussain R, Smego R Jr: Comparative features and outcomes of malaria at a tertiary care hospital in Karachi, Pakistan. Int J Infect Dis 2008, 12:37-42.

12. Kochar DK, Saxena V, Singh N, Kochar SK, Kumar SV, Das A: Plasmodium vivax malaria. Emerg Infect Dis 2005, 11:132-134.

13. Lawn SD, Krishna S, Jarvis JN, Joet T, Macallan DC: Case reports: pernicious complications of benign tertian malaria. Trans R Soc Trop Med Hyg 2003, 97:551-553

14. Genton B, D'Acremont V, Rare L, Baea K, Reeder JC, Alpers MP, Muller I: Plasmodium vivax and mixed infections are associated with severe malaria in children: a prospective cohort study from Papua New Guinea. PLoS Med 2008, 5:e127.

15. Barcus MJ, Basri H, Picarima H, Manyakori C, Sekartuti, Elyazar I, Bangs MJ, Maguire JD, Baird JK: Demographic risk factors for severe and fatal vivax and falciparum malaria among hospital admissions in Northeastern Indonesian Papua. Am J Trop Med Hyg 2007, 77:984-991.
16. Tjitra E, Anstey NM, Sugiarto P, Warikar N, Kenangalem E, Karyana M, Lampah DA, Price RN: Multidrug-resistant Plasmodium vivax associated with severe and fatal malaria: a prospective study in Papua, Indonesia. PLoS Med 2008, 5:e128.

17. Rodriguez-Morales AJ, Benitez JA, Arria M: Malaria mortality in Venezuela: focus on deaths due to Plasmodium vivax in children. J Trop Pediatr 2008, 54:94-101.

18. Price RN, Douglas NM, Anstey NM: New developments in Plasmodium vivax malaria: severe disease and the rise of chloroquine resistance. Curr Opin Infect Dis 2009, 22:430-435.

19. Baird JK: Neglect of Plasmodium vivax malaria. Trends Parasitol 2007, 23:533-539.

20. Maguire JD, Baird JK: The 'non-falciparum' malarias: the roles of epidemiology, parasite biology, clinical syndromes, complications and diagnostic rigour in guiding therapeutic strategies. Ann Trop Med Parasitol 2010, 104:283-301.

21. Baird JK: Severe and fatal vivax malaria challenges 'benign tertian malaria' dogma. Ann Trop Paediatr 2009, 29:251-252.

22. Anstey NM, Russell B, Yeo TW, Price RN: The pathophysiology of vivax malaria. Trends Parasitol 2009, 25:220-227.

23. Tan LKK, Yacoub S, Scott S, Bhagani S, Jacobs M: Acute lung injury and other serious complications of Plasmodium vivax malaria. Lancet Infect Dis 2008, 8:449-454.

24. Bassat $\mathrm{Q}$, Alonso PL: Defying malaria: fathoming severe Plasmodium vivax disease. Nat Med 2011, 17:48-49.

25. Rodriguez-Morales AJ, Sanchez E, Vargas M, Piccolo C, Colina R, Arria M: Anemia and thrombocytopenia in children with Plasmodium vivax malaria. J Trop Pediatr 2006, 52:49-51.

26. Rodriguez-Morales AJ, Sanchez E, Vargas M, Piccolo C, Colina R, Arria M, Franco-Paredes C: Is anemia in Plasmodium vivax malaria more frequent and severe than in Plasmodium falciparum? Am J Med 2006, 119:e9-e10.

27. Poespoprodjo JR, Fobia W, Kenangalem E, Lampah DA, Hasanuddin A, Warikar N, Sugiarto P, Tjitra E, Anstey NM, Price RN: Vivax malaria: a major cause of morbidity in early infancy. Clin Infect Dis 2009, 48:1704-1712.

28. Miller LH, Mason SJ, Clyde DF, McGinniss MH: The resistance factor to Plasmodium vivax in blacks. The Duffy-blood-group genotype, FyFy. N Engl J Med 1976, 295:302-304.

29. Menard D, Barnadas C, Bouchier C, Henry-Halldin C, Gray LR, Ratsimbasoa A, Thonier V, Carod JF, Domarle O, Colin Y, Bertrand O, Picot J, King CL, Grimberg BT, Mercereau-Puijalon O, Zimmerman PA: Plasmodium vivax clinical malaria is commonly observed in Duffy-negative Malagasy people. Proc Natl Acad Sci U S A 2010, 107:5967-5971.

30. Michon P, Cole-Tobian JL, Dabod E, Schoepflin S, Igu J, Susapu M, Tarongka N, Zimmerman PA, Reeder JC, Beeson JG, Schofield L, King CL, Mueller I: The risk of malarial infections and disease in Papua New Guinean children. Am J Trop Med Hyg 2007, 76:997-1008.

31. Lin E, Kiniboro B, Gray L, Dobbie S, Robinson L, Laumaea A, Schopflin S, Stanisic D, Betuela I, Blood-Zikursh M, Siba P, Felger I, Schofield L, Zimmerman P, Mueller I: Differential patterns of infection and disease with $P$. falciparum and $P$. vivax in young Papua New Guinean children. PLoS One 2010, 5:e9047.

32. Ladeia-Andrade S, Ferreira MU, de Carvalho ME, Curado I, Coura JR: Agedependent acquisition of protective immunity to malaria in riverine populations of the Amazon Basin of Brazil. Am J Trop Med Hyg 2009, 80:452-459.

33. Hill E, Amatuzio DS: Southwest Pacific vivax malaria: clinical features and observations concerning duration of clinical activity. Am J Trop Med 1949, s1-29:203-214

34. Coatney GR, Cooper WC, Young MD: Studies in human malaria. XXX. A summary of 204 sporozoite-induced infections with the Chesson strain of Plasmodium vivax. I Natl Malaria Soc 1950, 9:381.

35. Poespoprodjo JR, Fobia W, Kenangalem E, Lampah DA, Warikar N, Seal A, McGready R, Sugiarto P, Tjitra E, Anstey NM, Price RN: Adverse pregnancy outcomes in an area where multidrug-resistant Plasmodium vivax and Plasmodium falciparum infections are endemic. Clin Infect Dis 2008, 46:1374-1381.

36. Nosten F, McGready R, Simpson JA, Thwai KL, Balkan S, Cho T, Hkirijaroen L, Looareesuwan S, White NJ: Effects of Plasmodium vivax malaria in pregnancy. Lancet 1999, 354:546-549.

37. Rodriquez-Morales AJ, Sanchez E, Vargas M, Piccolo C, Colina R, Arria M, Franco-Paredes C: Pregnancy outcomes associated with Plasmodium vivax malaria in Northeastern Venezuela. Am J Trop Med Hyg 2006, 74:755-757. 
38. Luzzatto L, Nwachuku-Jarrett ES, Reddy S: Increased sickling of parasitised erythrocytes as mechanism of resistance against malaria in the sickle-cell trait. Lancet 1970, 1:319-321.

39. Roth EF Jr, Friedman M, Ueda Y, Tellez I, Trager W, Nagel RL: Sickling rates of human AS red cells infected in vitro with Plasmodium falciparum malaria. Science 1978, 202:650-652.

40. Weatherall DJ, Miller LH, Baruch DI, Marsh K, Doumbo OK, Casals-Pascual C, Roberts DJ: Malaria and the red cell. Hematology 2002:35-57.

41. Fowkes FJ, Allen S, Allen A, Alpers MP, Weatherall DJ, Day KP: Increased microerythrocyte count in homozygous alpha + -thalassaemia contributes to protection against severe malarial anaemia. PLOS Med 2008, 5:e56.

42. Williams TN, Maitland K, Bennett S, Ganczakowski M, Peto TE, Newbold Cl, Bowden DK, Weatherall DJ, Clegg JB: High incidence of malaria in alpha-thalassaemic children. Nature 1996, 383:522-525.

43. O'Donnell A, Premawardhena A, Arambepola M, Samaranayake R, Allen SJ, Peto TE, Fisher CA, Cook J, Corran PH, Olivieri NF, Weatherall DJ: Interaction of malaria with a common form of severe thalassemia in an Asian population. Proc Natl Acad Sci U S A 2009, 106:18716-18721.

44. Zimmerman PA, Woolley I, Masinde GL, Miller SM, McNamara DT, Hazlett F, Mgone CS, Alpers MP, Genton B, Boatin BA, Kazura JW: Emergence of FY*A (null) in a Plasmodium vivax-endemic region of Papua New Guinea. Proc Natl Acad Sci U S A 1999, 96:13973-13977.

45. Cattani JA, Gibson FD, Alpers MP, Crane GG: Hereditary ovalocytosis and reduced susceptibility to malaria in Papua New Guinea. Trans $R$ Soc Trop Med Hyg 1987, 81:705-709.

46. Rosanas-Urgell A, Lin E, Manning L, Rarau P, Laman M, Senn N, Grimberg BT, Tavul L, Stanisic D, Aponte J, Daboud E, Reeder JC, Siba P, Zimmerman PA, Davis TME, King CL, Michon P, Mueller I: Reduced risk of Plasmodium vivax malaria in Papua New Guinean children with South East Asian ovalocytosis. In Molecular Approaches to Malaria; Lorne, Victoria. Melbourne: Walter and Eliza Hall Institute; 2012:107.

47. Patel SS, King CL, Mgone CS, Kazura JW, Zimmerman PA: Glycophorin C (Gerbich antigen blood group) and band 3 polymorphisms in two malaria holoendemic regions of Papua New Guinea. Am J Hematol 2004, 75:1-5.

48. Louicharoen C, Patin E, Paul R, Nuchprayoon I, Witoonpanich B, Peerapittayamongkol C, Casademont I, Sura T, Laird NM, Singhasivanon P, Quintana-Murci L, Sakuntabhai A: Positively selected G6PD-Mahidol mutation reduces Plasmodium vivax density in Southeast Asians. Science 2009, 326:1546-1549.

49. Leslie T, Briceno M, Mayan I, Mohammed N, Klinkenberg E, Sibley CH, Whitty CJ, Rowland M: The impact of phenotypic and genotypic G6PD deficiency on risk of Plasmodium vivax infection: a case-control study amongst Afghan refugees in Pakistan. PLoS Med 2010, 7:e1000283.

50. Brooker S, Akhwale W, Pullan R, Estambale B, Clarke SE, Snow RW, Hotez PJ: Epidemiology of Plasmodium-helminth co-infection in Africa: populations at risk, potential impact on anemia, and prospects for combining control. Am J Trop Med Hyg 2007, 77:88-98.

51. Nacher $M$, Singhasivanon $P$, Yimsamran S, Manibunyong $W$, Thanyavanich $N$ Wuthisen R, Looareesuwan S: Intestinal helminth infections are associated with increased incidence of Plasmodium falciparum malaria in Thailand. J Parasitol 2002, 88:55-58.

52. Spiegel A, Tall A, Raphenon G, Trape JF, Druilhe P: Increased frequency of malaria attacks in subjects co-infected by intestinal worms and Plasmodium falciparum malaria. Trans R Soc Trop Med Hyg 2003, 97:198-199.

53. Boel M, Carrara VI, Rijken M, Proux S, Nacher M, Pimanpanarak M, Paw MK, Moo O, Gay H, Bailey W, Singhasivanon P, White NJ, Nosten F, McGready R: Complex interactions between soil-transmitted helminths and malaria in pregnant women on the Thai-Burmese border. PLoS Negl Trop Dis 2010, 4:e887.

54. Melo GC, Reyes-Lecca RC, Vitor-Silva S, Monteiro WM, Martins M, Benzecry SG, Alecrim MG, Lacerda MV: Concurrent helminthic infection protects schoolchildren with Plasmodium vivax from anemia. PLoS One 2010, 5:e11206.

55. Nyakeriga AM, Troye-Blomberg M, Dorfman JR, Alexander ND, Back R, Kortok M, Chemtai AK, Marsh K, Williams TN: Iron deficiency and malaria among children living on the coast of Kenya. J Infect Dis 2004, 190:439-447.

56. Sazawal S, Black RE, Ramsan M, Chwaya HM, Stoltzfus RJ, Dutta A, Dhingra U, Kabole I, Deb S, Othman MK, Kabole FM: Effects of routine prophylactic supplementation with iron and folic acid on admission to hospital and mortality in preschool children in a high malaria transmission setting: community-based, randomised, placebo-controlled trial. Lancet 2006, 367:133-143.
57. Nacher M, McGready R, Stepniewska K, Cho T, Looareesuwan S, White NJ, Nosten F: Haematinic treatment of anaemia increases the risk of Plasmodium vivax malaria in pregnancy. Trans R Soc Trop Med Hyg 2003, 97:273-276.

58. Richard SA, Zavaleta N, Caulfield LE, Black RE, Witzig RS, Shankar AH: Zinc and iron supplementation and malaria, diarrhea, and respiratory infections in children in the Peruvian Amazon. Am J Trop Med Hyg 2006, 75:126-132.

59. Harvey PW, Heywood PF, Nesheim MC, Galme K, Zegans M, Habicht JP Stephenson LS, Radimer KL, Brabin B, Forsyth K, Alpers MP: The effect of iron therapy on malarial infection in Papua New Guinean schoolchildren. Am J Trop Med Hyg 1989, 40:12-18.

60. Kitchen SF: The infection of reticulocytes by Plasmodium vivax. Am J Trop Med Hyg 1938, s1-18:347-359.

61. Vryonis G: Observations on the parasitization of erythrocytes by Plasmodium vivax, with special reference to reticulocytes. Am J Hyg 1939, 30:41-48.

62. Simpson JA, Silamut K, Chotivanich K, Pukrittayakamee S, White NJ: Red cell selectivity in malaria: a study of multiple-infected erythrocytes. Trans $R$ Soc Trop Med Hyg 1999, 93:165-168.

63. McQueen PG, McKenzie FE: Age-structured red blood cell susceptibility and the dynamics of malaria infections. Proc Natl Acad Sci U S A 2004, 101:9161-9166.

64. McQueen PG: Population dynamics of a pathogen: the conundrum of vivax malaria. Biophys Rev 2010, 2:111-120.

65. Antia R, Yates A, de Roode JC: The dynamics of acute malaria infections. I. Effect of the parasite's red blood cell preference. Proc Bio/ Sci 2008, 275:1449-1458.

66. Abdalla $S$, Weatherall DJ, Wickramasinghe $\mathrm{SN}$, Hughes M: The anaemia of $P$. falciparum malaria. Br J Haematol 1980, 46:171-183.

67. Jakeman GN, Saul A, Hogarth WL, Collins WE: Anaemia of acute malaria infections in non-immune patients primarily results from destruction of uninfected erythrocytes. Parasitology 1999, 119:127-133.

68. Weatherall DJ, Abdalla S: The anaemia of Plasmodium falciparum malaria. Br Med Bull 1982, 38:147-151.

69. Wickramasinghe $\mathrm{SN}$, Abdalla $\mathrm{SH}$ : Blood and bone marrow changes in malaria. Baillieres Best Pract Res Clin Haematol 2000, 13:277-299.

70. Price RN, Simpson JA, Nosten F, Luxemburger C, Hkirijaroen L, ter Kuile F, Chongsuphajaisiddhi T, White NJ: Factors contributing to anemia after uncomplicated falciparum malaria. Am J Trop Med Hyg 2001, 65:614-622.

71. Fendel R, Brandts C, Rudat A, Kreidenweiss A, Steur C, Appelmann I, Ruehe B, Schroder P, Berdel WE, Kremsner PG, Mordmuller B: Hemolysis is associated with low reticulocyte production index and predicts blood transfusion in severe malarial anemia. PLoS One 2010, 5:e10038.

72. Selvam R, Baskaran G: Hematological impairments in recurrent Plasmodium vivax infected patients. Jpn J Med Sci Biol 1996, 49:151-165.

73. Collins WE, Jeffery GM, Roberts JM: A retrospective examination of anemia during infection of humans with Plasmodium vivax. Am J Trop Med Hyg 2003, 68:410-412.

74. Prommano O, Chaisri U, Turner GD, Wilairatana P, Ferguson DJ, Viriyavejakul $P$, White NJ, Pongponratn E: A quantitative ultrastructural study of the liver and the spleen in fatal falciparum malaria. Southeast Asian J Trop Med Public Health 2005, 36:1359-1370.

75. Bruetsch WL: The histopathology of therapeutic (tertian) malaria. Am J Psychiatry 1932, 89:19-65.

76. Wickramasinghe SN, Looareesuwan S, Nagachinta B, White NJ: Dyserythropoiesis and ineffective erythropoiesis in Plasmodium vivax malaria. Br J Haematol 1989, 72:91-99.

77. Srichaikul T, Wasanasomsithi M, Poshyachinda V, Panikbutr N, Rabieb T: Ferrokinetic studies and erythropoiesis in malaria. Arch Intern Med 1969, 124:623-628.

78. Ru YX, Mao BY, Zhang FK, Pang TX, Zhao SX, Liu JH, Wickramasinghe $\mathrm{SN}$ : Invasion of erythroblasts by Pasmodium vivax: a new mechanism contributing to malarial anemia. Ultrastruct Pathol 2009, 33:236-242.

79. Yoeli M: Non-pigmented malaria parasites in the bone marrow from a mixed infection of Leishmania and Plasmodium vivax. Trans $R$ Soc Trop Med Hyg 1948, 42:99-101.

80. Marchiafava E, Bignami A: On summer-autumnal malaria fevers. London: The New Sydenham Society; 1894

81. Handayani S, Chiu DT, Tjitra E, Kuo JS, Lampah D, Kenangalem E, Renia L, Snounou G, Price RN, Anstey NM, Russell B: High deformability of 
Plasmodium vivax-infected red blood cells under microfluidic conditions. $J$ Infect Dis 2009, 199:445-450.

82. Dondorp AM, Angus BJ, Chotivanich K, Silamut K, Ruangveerayuth R, Hardeman MR, Kager PA, Vreeken J, White NJ: Red blood cell deformability as a predictor of anemia in severe falciparum malaria. Am J Trop Med Hyg 1999, 60:733-737.

83. Li J, Huang YX, Ji T, Tu M, Mao X, Chen WX, Chen GW: Non-invasive in situ simultaneous measurement of multi-parameter mechanical properties of red blood cell membrane. Acta Biochim Biophys Sin (Shanghai) 2005, 37:391-395.

84. Buffet PA, Milon G, Brousse V, Correas JM, Dousset B, Couvelard A, Kianmanesh R, Farges O, Sauvanet A, Paye F, Ungeheuer MN, Ottone C, Khun H, Fiette L, Guigon G, Huerre M, Mercereau-Puijalon O, David PH: Ex vivo perfusion of human spleens maintains clearing and processing functions. Blood 2006, 107:3745-3752.

85. Cranston HA, Boylan CW, Carroll GL, Sutera SP, Williamson JR, Gluzman IY, Krogstad DJ: Plasmodium falciparum maturation abolishes physiologic red cell deformability. Science 1984, 223:400-403.

86. Deplaine G, Safeukui I, Jeddi F, Lacoste F, Brousse V, Perrot S, Biligui S, Guillotte M, Guitton C, Dokmak S, Aussilhou B, Sauvanet A, Cazals Hatem D, Paye F, Thellier M, Mazier D, Milon G, Mohandas N, Mercereau-Puijalon O, David PH, Buffet PA: The sensing of poorly deformable red blood cells by the human spleen can be mimicked in vitro. Blood 2011, 117:e88-e95.

87. Safeukui I, Correas JM, Brousse V, Hirt D, Deplaine G, Mule S, Lesurtel M, Goasguen N, Sauvanet A, Couvelard A, Kerneis S, Khun H, Vigan-Womas I, Ottone C, Molina TJ, Treluyer JM, Mercereau-Puijalon O, Milon G, David PH, Buffet PA: Retention of Plasmodium falciparum ring-infected erythrocytes in the slow, open microcirculation of the human spleen. Blood 2008, 112:2520-2528.

88. Pouvelle B, Buffet PA, Lepolard C, Scherf A, Gysin J: Cytoadhesion of Plasmodium falciparum ring-stage-infected erythrocytes. Nat Med 2000, 6:1264-1268.

89. Goka BQ, Kwarko H, Kurtzhals JA, Gyan B, Ofori-Adjei E, Ohene SA, Hviid L, Akanmori BD, Neequaye J: Complement binding to erythrocytes is associated with macrophage activation and reduced haemoglobin in Plasmodium falciparum malaria. Trans $R$ Soc Trop Med Hyg 2001, 95:545-549.

90. Pawluczkowycz AW, Lindorfer MA, Waitumbi JN, Taylor RP: Hematin promotes complement alternative pathway-mediated deposition of C3 activation fragments on human erythrocytes: potential implications for the pathogenesis of anemia in malaria. J Immunol 2007, 179:5543-5552.

91. Waitumbi JN, Opollo MO, Muga RO, Misore AO, Stoute JA: Red cell surface changes and erythrophagocytosis in children with severe Plasmodium falciparum anemia. Blood 2000, 95:1481-1486.

92. Awah $N$, Balogun $H$, Achidi $E$, Mariuba LA, Nogueira PA, Orlandi $P$, Troye-Blomberg M, Gysin J, Berzins K: Antibodies to the Plasmodium falciparum rhoptry protein RAP-2/RSP-2 in relation to anaemia in Cameroonian children. Parasite Immunol 2011, 33:104-115.

93. Bhattacharya J, Swarup-Mitra S: Reduction in erythrocytic GSH level and stability in Plasmodium vivax malaria. Trans R Soc Trop Med Hyg 1987, 81:64-66.

94. Nuchsongsin F, Chotivanich K, Charunwatthana P, Omodeo-Sale F, Taramelli D, Day NP, White NJ, Dondorp AM: Effects of malaria heme products on red blood cell deformability. Am J Trop Med Hyg 2007, 77:617-622.

95. Omodeo-Sale F, Motti A, Dondorp A, White NJ, Taramelli D: Destabilisation and subsequent lysis of human erythrocytes induced by Plasmodium falciparum haem products. Eur I Haematol 2005, 74:324-332.

96. Kurtzhals JA, Adabayeri V, Goka BQ, Akanmori BD, Oliver-Commey JO, Nkrumah FK, Behr C, Hviid L: Low plasma concentrations of interleukin 10 in severe malarial anaemia compared with cerebral and uncomplicated malaria. Lancet 1998, 351:1768-1772.

97. Thuma PE, van Dijk J, Bucala R, Debebe Z, Nekhai S, Kuddo T, Nouraie M, Weiss $G$, Gordeuk VR: Distinct clinical and immunologic profiles in severe malarial anemia and cerebral malaria in Zambia. J Infect Dis 2011, 203:211-219.

98. Layez C, Nogueira P, Combes V, Costa FT, Juhan-Vague I, da Silva LH, Gysin $\mathrm{J}$ : Plasmodium falciparum rhoptry protein RSP2 triggers destruction of the erythroid lineage. Blood 2005, 106:3632-3638.

99. de Mast Q, Syafruddin D, Keijmel S, Riekerink TO, Deky O, Asih PB, Swinkels DW, van der Ven AJ: Increased serum hepcidin and alterations in blood iron parameters associated with asymptomatic $P$. falciparum and $P$. vivax malaria. Haematologica 2010, 95:1068-1074.
100. Burchard GD, Radloff P, Philipps J, Nkeyi M, Knobloch J, Kremsner PG: Increased erythropoietin production in children with severe malarial anemia. Am J Trop Med Hyg 1995, 53:547-551.

101. Kurtzhals JA, Rodrigues O, Addae M, Commey JO, Nkrumah FK, Hviid L: Reversible suppression of bone marrow response to erythropoietin in Plasmodium falciparum malaria. Br J Haematol 1997, 97:169-174.

102. Burgmann H, Looareesuwan S, Kapiotis S, Viravan C, Vanijanonta S, Hollenstein U, Wiesinger E, Presterl E, Winkler S, Graninger W: Serum levels of erythropoietin in acute Plasmodium falciparum malaria. Am J Trop Med Hyg 1996, 54:280-283.

103. el Hassan AM, Saeed AM, Fandrey J, Jelkmann W: Decreased erythropoietin response in Plasmodium falciparum malaria-associated anaemia. Eur $\lrcorner$ Haematol 1997, 59:299-304.

104. Gwamaka M, Fried M, Domingo G, Duffy PE: Early and extensive CD55 loss from red blood cells supports a causal role in malarial anaemia. Malar J 2011, 10:386.

105. Fernandes AA, Carvalho LJ, Zanini GM, Ventura AM, Souza JM, Cotias PM, Silva-Filho IL, Daniel-Ribeiro CT: Similar cytokine responses and degrees of anemia in patients with Plasmodium falciparum and Plasmodium vivax infections in the Brazilian Amazon region. Clin Vaccine Immunol 2008, 15:650-658.

106. Chotivanich KT, Pukrittayakamee S, Simpson JA, White NJ, Udomsangpetch $\mathrm{R}$ : Characteristics of Plasmodium vivax-infected erythrocyte rosettes. Am J Trop Med Hyg 1998, 59:73-76.

107. Udomsanpetch R, Thanikkul K, Pukrittayakamee S, White NJ: Rosette formation by Plasmodium vivax. Trans R Soc Trop Med Hyg 1995, 89:635-637.

108. del Portillo HA, Lanzer M, Rodriguez-Malaga S, Zavala F, Fernandez-Becerra C: Variant genes and the spleen in Plasmodium vivax malaria. Int $J$ Parasitol 2004, 34:1547-1554.

109. Anstey NM, Handojo T, Pain MCF, Kenangalem E, Tjitra E, Price RN, Maguire GP: Lung injury in vivax malaria: pathophysiological evidence for pulmonary vascular sequestration and posttreatment alveolar-capillary inflammation. J Infect Dis 2007, 195:589-596.

110. Suwanarusk R, Cooke BM, Dondorp AM, Silamut K, Sattabongkot J, White NJ, Udomsangpetch $R$ : The deformability of red blood cells parasitized by Plasmodium falciparum and P. vivax. J Infect Dis 2004, 189:190-194.

111. Bass CC: An attempt to explain the greater pathogenicity of Plasmodium falciparum as compared with other species. Am J Trop Med 1921, s1-1:29-33.

112. Kumaresan PR, Selvam R: The haematology of Plasmodium vivax before and after chloroquine and primaquine treatment in North Madras area. Indian J Malariol 1991, 28:115-120.

113. Karunaweera ND, Wijesekera SK, Wanasekera D, Mendis KN, Carter R: The paroxysm of Plasmodium vivax malaria. Trends Parasitol 2003, 19:188-193.

114. Mendis KN, Carter R: The role of cytokines in Plasmodium vivax malaria. Mem Inst Oswaldo Cruz 1992, 87(Suppl 3):51-55.

115. Yeo TW, Lampah DA, Tjitra E, Piera K, Gitawati R, Kenangalem E, Price RN, Anstey NM: Greater endothelial activation, Weibel-Palade body release and host inflammatory response to Plasmodium vivax, compared with Plasmodium falciparum: a prospective study in Papua, Indonesia. J Infect Dis 2010, 202:109-112.

116. Hemmer CJ, Holst FGE, Kern P, Chiwakata CB, Dietrich M, Reisinger EC: Stronger host response per parasitized erythrocyte in Plasmodium vivax or ovale then in Plasmodium falciparum malaria. Trop Med Int Health 2006, $11: 817-823$

117. Meera S, Rao AV, D'Souza V, Rao SB: In vitro studies on peroxidative changes leading to hemolysis of erythrocytes infested with malarial parasite Plasmodium vivax. Indian J Exp Biol 1999, 37:729-730.

118. Erel O, Kocyigit A, Avci S, Aktepe N, Bulut V: Oxidative stress and antioxidative status of plasma and erythrocytes in patients with vivax malaria. Clin Biochem 1997, 30:631-639.

119. Ekvall H: Malaria and anemia. Curr Opin Hematol 2003, 10:108-114.

120. Greve B, Kremsner PG, Lell B, Luckner D, Schmid D: Malarial anaemia in African children associated with high oxygen-radical production. Lancet 2000, 355:40-41.

121. Griffiths MJ, Ndungu F, Baird KL, Muller DP, Marsh K, Newton CR: Oxidative stress and erythrocyte damage in Kenyan children with severe Plasmodium falciparum malaria. Br J Haematol 2001, 113:486-491.

122. Fulton JD, Grant PT: The sulphur requirements of the erythrocytic form of Plasmodium knowlesi. Biochem J 1956, 63:274-282.

123. Lamikanra AA, Brown D, Potocnik A, Casals-Pascual C, Langhorne J, Roberts DJ: Malarial anemia: of mice and men. Blood 2007, 110:18-28. 
124. Buffet PA, Safeukui I, Milon G, Mercereau-Puijalon O, David PH: Retention of erythrocytes in the spleen: a double-edged process in human malaria. Curr Opin Hematol 2009, 16:157-164.

125. Buffet PA, Safeukui I, Deplaine G, Brousse V, Prendki V, Thellier M, Turner GD, Mercereau-Puijalon O: The pathogenesis of Plasmodium falciparum malaria in humans: insights from splenic physiology. Blood 2011, 117:381-392.

126. Looareesuwan S, Ho M, Wattanagoon Y, White NJ, Warrell DA, Bunnag D, Harinasuta T, Wyler DJ: Dynamic alteration in splenic function during acute falciparum malaria. N Engl J Med 1987, 317:675-679.

127. World Health Organization: Severe falciparum malaria. Trans $R$ Soc Trop Med Hyg 2000, 94:S1-S90.

128. Giha HA, Elghazali G, Elgadir TM, Elbasit IE, Elbashir MI: Severe malaria in an unstable setting: clinical and laboratory correlates of cerebral malaria and severe malarial anemia and a paradigm for a simplified severity scoring. Eur J Clin Microbiol Infect Dis 2009, 28:661-665.

129. Marsh K, Forster D, Waruiru C, Mwangi I, Winstanley P, Marsh V, Newton C, Winstanley P, Warn P, Peshu N, Pasvol G, Snow R: Indicators of lifethreatening malaria in African children. N Engl J Med 1995, 332:1399-1404.

130. Crane GG, Pryor DS: Malaria and the tropical splenomegaly syndrome in New Guinea. Trans R Soc Trop Med Hyg 1971, 65:315-324.

131. Crane GG, Gardner A, Hudson P, Hudson B, Voller A: Malarial antibodies in tropical splenomegaly syndrome in Papua New Guinea. Trans $R$ Soc Trop Med Hyg 1977, 71:308-314.

132. Imbert $P$, Rapp C, Buffet PA: Pathological rupture of the spleen in malaria: analysis of 55 cases (1958-2008). Travel Med Infect Dis 2009, 7:147-159.

133. Ozsoy MF, Oncul O, Pekkafali Z, Pahsa A, Yenen OS: Splenic complications in malaria: report of two cases from Turkey. J Med Microbio/ 2004, 53:1255-1258

134. Littman E: Splenectomy in hereditary spherocytosis: effect on course of relapsing vivax malaria. Am J Med Sci 1974, 267:53-56.

135. Looareesuwan S, Merry AH, Phillips RE, Pleehachinda R, Wattanagoon Y, Ho M, Charoenlarp P, Warrell DA, Weatherall DJ: Reduced erythrocyte survival following clearance of malarial parasitaemia in Thai patients. $\mathrm{Br} J$ Haematol 1987, 67:473-478.

136. Woodruff AW, Ansdell VE, Pettitt LE: Cause of anaemia in malaria. Lancet 1979, 1:1055-1057

137. Gandapur AS, Malik SA, Raziq F: Bone marrow changes in human malaria: a retrospective study. J Pak Med Assoc 1997, 47:137-139.

138. Chang K-H, Stevenson MM: Malarial anaemia: mechanisms and implications of insufficient erythropoiesis during blood-stage malaria. Int J Parasitol 2004, 34:1501-1516.

139. Vedovato M, De Paoli Vitali E, Dapporto M, Salvatorelli G: Defective erythropoietin production in the anaemia of malaria. Nephrol Dial Transplant 1999, 14:1043-1044.

140. Boyd MF: The threshold of parasite density in relation to clinical activity in primary infections with Plasmodium vivax. Am J Trop Med 1938, s1-18:497-503.

141. Coatney GR, Cooper WC, Ruhe DS, Young MD, Burgess RW: Studies in human malaria: XVIII. The life pattern of sporozoite-induced St. Elizabeth strain vivax malaria. Am J Epid 1950, 51:200

142. Boyd MF, Kitchen SF: On the efficiency of the homologous properties of acquired immunity to Plasmodium vivax. Am J Trop Med 1936, s1-16:447-457.

143. Boyd MF: Criteria of immunity and susceptibility in naturally induced vivax malaria infections. Am J Trop Med 1942, s1-22:217-226.

144. Collins WE, Jeffery GM, Roberts JM: A retrospective examination of reinfection of humans with Plasmodium vivax. Am J Trop Med Hyg 2004, 70:642-644.

145. Boyd MF, Stratman-Thomas WK, Kitchen SF: On the duration of acquired homologous immunity to Plasmodium vivax. Am J Trop Med 1936, s1-16:311-315.

146. Boyd MF, Kitchen SF: Recurring clinical activity in infections with the McCoy strain of Plasmodium vivax. Am J Trop Med 1937, s1-17:833-843.

147. Boyd MF, Matthews CB: Further observations on the duration of immunity to the homologous strain of Plasmodium vivax. Am J Trop Med 1939, s1-19:63-67.

148. Boyd MF, Kitchen SF: Renewed clinical activity in naturally induced vivax malaria. Am J Trop Med 1944, s1-24:221-234

149. Young MD, Ellis JM, Stubbs TH: Some characteristics of foreign vivax malaria induced in neurosyphilitic patients. Am J Trop Med 1947, s1-27:585-596.

150. Douglas NM, Nosten F, Ashley EA, Phaipun L, van Vugt M, Singhasivanon $P$, White NJ, Price RN: Plasmodium vivax recurrence following falciparum and mixed species malaria: risk factors and effect of antimalarial kinetics. Clin Infect Dis 2011, 52:612-620.

151. Cui L, Escalante AA, Imwong M, Snounou G: The genetic diversity of Plasmodium vivax populations. Trends Parasitol 2003, 19:220-226.

152. Imwong M, Snounou G, Pukrittayakamee S, Tanomsing N, Kim JR, Nandy A, Guthmann JP, Nosten F, Carlton J, Looareesuwan S, Nair S, Sudimack D, Day NP, Anderson TJ, White NJ: Relapses of Plasmodium vivax infection usually result from activation of heterologous hypnozoites. J Infect Dis 2007, 195:927-933.

153. Chen N, Auliff A, Rieckmann K, Gatton M, Cheng Q: Relapses of Plasmodium vivax infection result from clonal hypnozoites activated at predetermined intervals. J Infect Dis 2007, 195:934-941.

154. Boyd MF, Kupper WH, Matthews CB: A deficient homologous immunity following simultaneous inoculation with two strains of Plasmodium vivax. Am J Trop Med 1938, s1-18:521-524.

155. Hankey DD, Jones R Jr, Coatney GR, Alving AS, Coker WG, Garrison PL, Donovan WN: Korean vivax malaria. I. natural history and response to chloroquine. Am J Trop Med Hyg 1953, 2:958-969.

156. Whorton CM, Yount E Jr, Jones R Jr, Alving AS: The Chesson strain of Plasmodium vivax malaria III: clinical aspects. J Infect Dis 1947, 80:237-249.

157. Looareesuwan S, White NJ, Chittamas S, Bunnag D, Harinasuta T: High rate of Plasmodium vivax relapse following treatment of falciparum malaria in Thailand. Lancet 1987, 2:1052-1055.

158. Siripoon N, Snounou G, Yamogkul P, Na-Bangchang K, Thaithong S: Cryptic Plasmodium falciparum parasites in clinical $P$. vivax blood samples from Thailand. Trans R Soc Trop Med Hyg 2002, 96:70-71.

159. Brown AE, Kain KC, Pipithkul J, Webster HK: Demonstration by the polymerase chain reaction of mixed Plasmodium falciparum and $P$. vivax infections undetected by conventional microscopy. Trans R Soc Trop Med Hyg 1992, 86:609-612.

160. Maitland K, Williams TN, Newbold Cl: Plasmodium vivax and P. falciparum: biological interactions and the possibility of cross-species immunity. Parasitol Today 1997, 13:227-231.

161. Luxemburger C, Ricci F, Nosten F, Raimond D, Bathet S, White NJ: The epidemiology of severe malaria in an area of low transmission in Thailand. Trans R Soc Trop Med Hyg 1997, 91:256-262.

162. Mayxay M, Pukrittayakamee S, Newton PN, White NJ: Mixed-species malaria infections in humans. Trends Parasitol 2004, 20:233-240.

163. Ratcliff A, Siswantoro H, Kenangalem E, Maristela R, Wuwung M, Laihad F, Ebsworth EP, Anstey NM, Tjitra E, Price RN: Two fixed-dose artemisinin combinations for drug-resistant falciparum and vivax malaria in Papua, Indonesia: an open-label randomised comparison. Lancet 2007, 369:757-765.

164. Price RN, Nosten F: Drug resistant falciparum malaria: clinical consequences and strategies for prevention. Drug Resist Updat 2001, 4:187-196.

165. Leslie T, Mayan MI, Hasan MA, Safi MH, Klinkenberg E, Whitty CJ, Rowland M: Sulfadoxine-pyrimethamine, chlorproguanil-dapsone, or chloroquine for the treatment of Plasmodium vivax malaria in Afghanistan and Pakistan: a randomized controlled trial. JAMA 2007, 297:2201-2209.

166. Kongpatanakul S, Chatsiricharoenkul S, Khuhapinant A, Atipas S, Kaewkungwal $\mathrm{J}$ : Comparative study of dihydroartemisinin and artesunate safety in healthy Thai volunteers. Int J Clin Pharmacol Ther 2009, 47:579-586.

167. Poravuth Y, Socheat D, Rueangweerayut R, Uthaisin C, Phyo AP, Valecha N, Rao BHK, Tjitra E, Purnama A, Borghini-Fuhrer I, Duparc S, Shin C, Fleckenstein L: Pyronaridine-artesunate versus chloroquine in patients with acute Plasmodium vivax malaria: a randomized, double-blind, noninferiority trial. PLOS One 2011, 6:e14501.

168. Finaurini S, Ronzoni L, Colancecco A, Cattaneo A, Cappellini MD, Ward SA, Taramelli D: Selective toxicity of dihydroartemisinin on human CD34+ erythroid cell differentiation. Toxicology 2010, 276:128-134

169. Sowunmi A, Balogun ST, Gbotosho GO, Happi CT: Effects of amodiaquine, artesunate, and artesunate-amodiaquine on Plasmodium falciparum malaria-associated anaemia in children. Acta Trop 2009, 109:55-60.

170. Yeka A, Banek K, Bakyaita N, Staedke SG, Kamya MR, Talisuna A, Kironde F, Nsobya SL, Kilian A, Slater M, Reingold A, Rosenthal PJ, Wabwire-Mangen F, Dorsey G: Artemisinin versus nonartemisinin combination therapy for uncomplicated malaria: randomized clinical trials from four sites in Uganda. PLoS Med 2005, 2:e190.

171. Pukrittayakamee S, Imwong M, Chotivanich K, Singhasivanon P, Day NP, White NJ: A comparison of two short-course primaquine regimens for the treatment and radical cure of Plasmodium vivax malaria in Thailand. Am J Trop Med Hyg 2010, 82:542-547. 
172. Anderson TJC, Nair S, Nkhoma S, Williams JT, Imwong M, Yi P, Socheat D, Das D, Chotivanich K, Day NPJ, White NJ, Dondorp AM: High heritability of malaria parasite clearance rate indicates a genetic basis for artemisinin resistance in Western Cambodia. J Infect Dis 2010, 201:1326-1330.

173. Yount EH Jr, Coggeshall LT: Status of immunity following cure of recurrent vivax malaria. Am J Trop Med 1949, s1-29:701-705.

174. Hasugian AR, Purba HLE, Kenangalem E, Wuwung RM, Ebsworth EP, Maristela R, Penttinen PMP, Laihad F, Anstey NM, Tjitra E, Price RN: Dihydroartemisinin-piperaquine versus artesunate-amodiaquine: superior efficacy and posttreatment prophylaxis against multidrug-resistant Plasmodium falciparum and Plasmodium vivax malaria. Clin Infect Dis 2007 44:1067-1074

175. Karunajeewa HA, Mueller I, Senn M, Lin E, Law I, Gomorrai PS, Oa O, Griffin S, Kotab K, Suano P, Tarongka N, Ura A, Lautu D, Page-Sharp M, Wong R, Salman S, Siba P, llett KF, Davis TME: A trial of combination antimalarial therapies in children from Papua New Guinea. N Engl J Med 2008, 359:2545-2557.

176. Imwong M, Pukrittayakamee S, Looareesuwan S, Pasvol G, Poirriez J, White $\mathrm{NJ}$, Snounou G: Association of genetic mutations in Plasmodium vivax $d h f r$ with resistance in sulfadoxine-pyrimethamine: geographical and clinical correlates. Antimicrob Agents Chemother 2001, 45:3122-3127.

177. Ekvall $H$, Premji Z, Bjorkman A: Chloroquine treatment for uncomplicated childhood malaria in an area with drug resistance: early treatment failure aggravates anaemia. Trans $R$ Soc Trop Med Hyg 1998, 92:556-560.

178. Baird JK, Hoffman SL: Primaquine therapy for malaria. Clin Infect Dis 2004, 39:1336-1345.

179. Beutler $E$ : The hemolytic effect of primaquine and related compounds: a review. Blood 1959, 14:103-139.

180. Nkhoma ET, Poole C, Vannappagari V, Hall SA, Beutler E: The global prevalence of glucose-6-phosphate dehydrogenase deficiency: a systematic review and meta-analysis. Blood Cells Mol Dis 2009, 42:267-278.

181. Baird JK, McCormick GJ, Canfield CJ: Effects of nine synthetic putative metabolites of primaquine on activity of the hexose monophosphate shunt in intact human red blood cells in vitro. Biochem Pharmacol 1986, 35:1099-1106.

182. Beutler E: G6PD: population genetics and clinical manifestations. Blood Rev 1996, 10:45-52.

183. Reeve PA, Toaliu H, Kaneko A, Hall JJ, Ganczakowski M: Acute intravascular haemolysis in Vanuatu following a single dose of primaquine in individuals with glucose-6-phosphate dehydrogenase deficiency. J Trop Med Hyg 1992, 95:349-351.

184. Alving AS, Johnson CF, Tarlov AR, Brewer GJ, Kellermeyer RW, Carson PE: Mitigation of the haemolytic effect of primaquine and enhancement of its action against exoerythrocytic forms of the Chesson strain of Plasmodium vivax by intermittent regimens of drug administration. Bull World Health Organ 1960, 22:621-631.

185. Leslie T, Mayan I, Mohammed N, Erasmus P, Kolaczinski J, Whitty CJ, Rowland M: A randomised trial of an eight-week, once weekly primaquine regimen to prevent relapse of Plasmodium vivax in Northwest Frontier Province, Pakistan. PLOS ONE 2008, 3:e2861.

186. Clyde DF: Clinical problems associated with the use of primaquine as a tissue schizontocidal and gametocytocidal drug. Bull World Health Organ 1981, 59:391-395.

187. Zalusky R: Drug-associated hemolytic anemia. Bull N Y Acad Med 1970, 46:427-437.

188. Alexandre MA, Ferreira CO, Siqueira AM, Magalhaes BL, Mourao MP, Lacerda MV, Alecrim MG: Severe Plasmodium vivax malaria, Brazilian Amazon. Emerg Infect Dis 2010, 16:1611-1614

189. Luxemburger C, Thwai KL, White NJ, Webster HK, Kyle DE, Maelankirri L, Chongsuphajaisiddhi T, Nosten F: The epidemiology of malaria in a Karen population on the western border of Thailand. Trans $R$ Soc Trop Med Hyg 1996, 90:105-111.

190. Spencer TE: Haemoglobin levels in the D'Entrecasteaux Islands in relation to malaria and nutrition. Med J Aust 1966, 2:1093-1097.

191. Brabin BJ, Hakimi M, Pelletier D: An analysis of anemia and pregnancy-related maternal mortality. J Nutr 2001, 131:604S-614S. discussion 614S-615S.

192. Brabin BJ, Premji Z, Verhoeff F: An analysis of anemia and child mortality. J Nutr 2001, 131:636S-645S. discussion 646S-648S.

193. World Health Organization: Global database on blood safety: report 2004-2005. Geneva: World Health Organization; 2008.
194. Jayaraman S, Chalabi Z, Perel P, Guerriero C, Roberts I: The risk of transfusion-transmitted infections in sub-Saharan Africa. Transfusion 2010, 50:433-442.

195. Brabin BJ, Ginny M, Sapau J, Galme K, Paino J: Consequences of maternal anaemia on outcome of pregnancy in a malaria endemic area in Papua New Guinea. Ann Trop Med Parasitol 1990, 84:11-24.

196. Swellengrebel NH, de Buck A: Malaria in The Netherlands. Amsterdam: Scheltema \& Holkema Ltd.; 1938.

197. Brooker S, Guyatt H, Omumbo J, Shretta R, Drake L, Ouma J: Situation analysis of malaria in school-aged children in Kenya - what can be done? Parasitol Today 2000, 16:183-186.

198. Fernando D, Wickremasinghe R, Mendis KN, Wickremasinghe AR: Cognitive performance at school entry of children living in malaria-endemic areas of Sri Lanka. Trans R Soc Trop Med Hyg 2003, 97:161-165.

199. Fernando SD, Gunawardena DM, Bandara MR, De Silva D, Carter R, Mendis KN, Wickremasinghe AR: The impact of repeated malaria attacks on the school performance of children. Am J Trop Med Hyg 2003, 69:582-588.

200. Fernando D, de Silva D, Wickremasinghe R: Short-term impact of an acute attack of malaria on the cognitive performance of schoolchildren living in a malaria-endemic area of Sri Lanka. Trans R Soc Trop Med Hyg 2003, 97:633-639.

201. Williams TN, Maitland K, Phelps L, Bennett S, Peto TE, Viji J, Timothy R, Clegg $J B$, Weatherall DJ, Bowden DK: Plasmodium vivax: a cause of malnutrition in young children. QJM 1997, 90:751-757.

202. Sachs J, Malaney P: The economic and social burden of malaria. Nature 2002, 415:680-685.

203. Van den Eede P, Soto-Calle VE, Delgado C, Gamboa D, Grande T, Rodriguez H, Llanos-Cuentas A, Anne J, D'Alessandro U, Erhart A: Plasmodium vivax subpatent infections after radical treatment are common in Peruvian patients: results of a 1-year prospective cohort study. PLoS One 2011, 6:e16257.

doi:10.1186/1475-2875-11-135

Cite this article as: Douglas et al:: The anaemia of Plasmodium vivax malaria. Malaria Journal $2012: 135$

\section{Submit your next manuscript to BioMed Central and take full advantage of:}

- Convenient online submission

- Thorough peer review

- No space constraints or color figure charges

- Immediate publication on acceptance

- Inclusion in PubMed, CAS, Scopus and Google Scholar

- Research which is freely available for redistribution 